\title{
The Growth of International Business
}

\author{
Suyash Bhargava ${ }^{1}$, Sunita Joshi ${ }^{2}$ \\ ${ }^{1}$ UG - Bachelor of Science Information Technology, MRIIRS, Faridabad, Haryana \\ ${ }^{2}$ Assistant Professor, Computer Application, MRIIRS, Faridabad, Haryana
}

\begin{abstract}
In the international business we have discuss about the business where we have sold and buy the product for making a profit and most of the cases, we have buying a goods and product to another country and we also sell the product like tea, coffee. The importance of the international business is to set up a multinational company in India and also, we meet the new technology and also, we earn foreign exchange because in this type of business all the goods and services are export in all over the world so the foreign is make a business more powerful and profitable and much more things. Even a country has a limited resources and cannot published all the good and services in all over the country it also invested world in the international production and trade and exchange this business is help to develop your normal business to grate business and multinational investment. And a fast-glowing market and there is need of incorporate into global product to respond to local competitors. So the trade is one of the nodes of international business and the strategy of the multinational firms by the tariff and non-tariff or to create a successful global strategy and understand the natural of global industries so, in the world economy we can see that international business has been the raise of Companies that operate a globally and the multinational from all countries in the world that is need to Be ensure that they don't fall local law and profit back to their home countries and the advantage of MNEs both are the destination for most global flow also a outward and inward for the direct investment So The importance of this type of business you can sell you product to all over the country and in the Country and it helps your business to grow up of your business and make a pro Of Development of International Business, Why International Business is Important
\end{abstract}

Keywords - Increased Revenue, Reaching New Customer, Foreign Exchange Market, Future

\section{INTRODUCTION}

International business is all about the trade and a goods, services, and the technology or the capital and know about the across the national borders and at a global scale [1] Global business strategy is the trade-off between global and local responsiveness and the result in four basic global business [2] Globalization seemed to be an unstoppable force The advanced economies host to the headquarters of most of the world's major multinational companies [3] To give to the customers all the easiest ways to connect to the company to the easiest way to go the latest modern technology and some applications in over the Internet.[4]

\section{Increase Revenue:}

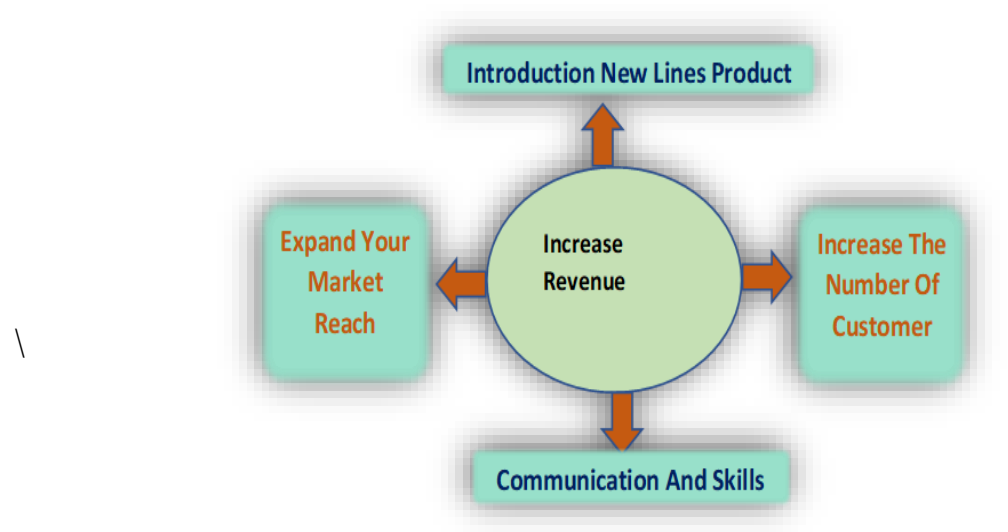

Fig 1. Method OF Increase Revenue

The advantage of increase revenue in the international business is to advance in trade to able to increase the number of clients of all the country and track to grow a business to increase the revenue and the MNC's have more customer in all 


\section{International Advanced Research Journal in Science, Engineering and Technology}

Vol. 8, Issue 6, June 2021

DOI: $10.17148 /$ IARJSET.2021.8697

over the country to approach to the customer in domestic area and companies for selling the product in global for the purpose of increase revenue for the organization.[5]

\section{Increase The Number of Customer:}

Frist You understand the customer needs and some market research, deliver the best services to the customer and they keep coming back or buying a product and take your business online mode also.

\section{communication and skills:}

This is important point in the international business. It allows you to understand another language and you can talk everyone all over the country in any culture peoples.

\section{REACHING NEW CUSTOMER:}

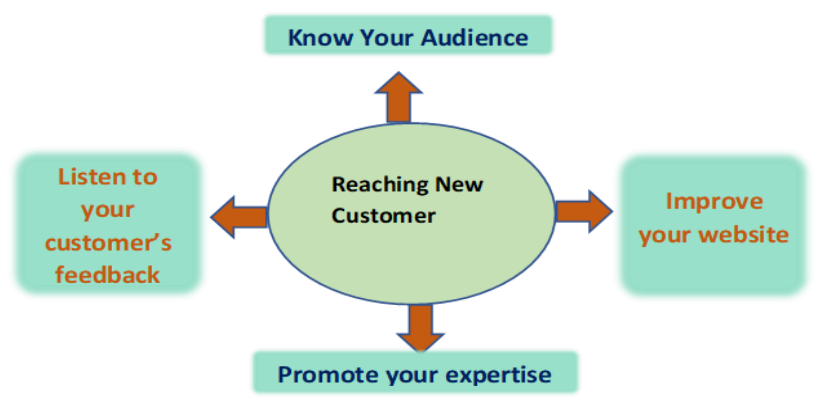

Fig 2. Method OF Reaching New Customer

International business is all about the approach the new customer in the current market if you need a customer to make a strategy that you are using in the business to introduce the new product and give better services and update with marketing material and also involved in community and network and place your business on online platform. There is a some MNC's have more customer in all over the country to reach globally.[6]

\section{$>\quad$ Promote Your Expertise:}

If you want new customers first you promote your expertise introduce new product on social media and also find your industry expertise and also sharing your expertise in your business

\section{$>\quad$ Know Your Audience:}

If you want to know your audience do research inn advance what they want check all the feedback and look at your competitors.

\section{FOREIGN EXCHANGE MARKET:}

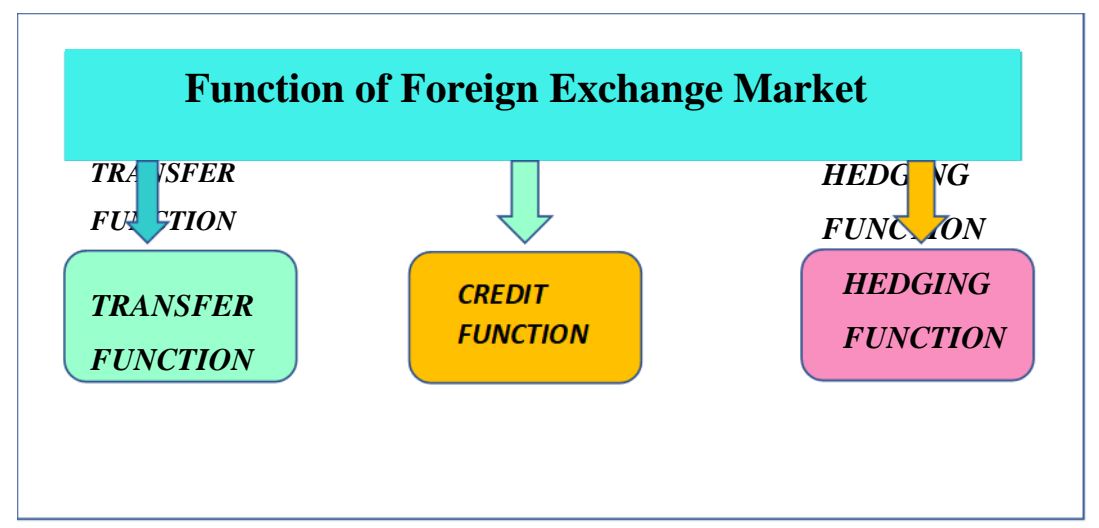

Fig 3. Function of Foreign Exchange Market

The foreign exchange market is a global market that determine foreign exchange rate for all the currency and it include buying and selling and in the international business they required the trading and investing assets and liabilities to the risk profit to the business. Exchange rate are the component by which global currencies are tired together in the global market and also provide the prize of currency in term of other.[7] 


\section{International Advanced Research Journal in Science, Engineering and Technology}

Vol. 8, Issue 6, June 2021

DOI: $10.17148 /$ IARJSET.2021.8697

Transfer Function:

This is the basic function of foreign exchange market is to a transfer purchasing power to between the two countries and the conversion of currency in other and performed credit instruments foreign bill and draft and for the settlement of payment.[8]

\section{Credit Function:}

This function is to provide a credit both the national and international foreign trade and it also use an international payment for a three month of maturity period. It is a smooth flow of goods and services for country to another country. It is a also good for importer to take a good and sell them and obtain money to pay a bill. [8]

$>\quad$ Hedging Function:

In this function there is some risk in the exchange market perform the hedging function this is a act of assets and liabilities in the foreign currency to avoiding the risk for effect the result for the future changes on value of foreign currency.[8]

\section{FUTURE DEVELOPMENT OF INTERNATIONAL BUSINESS:}

In the future there is great scope in the international business because it gives you better strategic, technology, communication and foreign exchange markets.In this business it gives a emerging market and contribute more global GDP today for developing market and it gives a demand from foreign market [10]. It also increases the globalization of the world economy it needs for the survival of business or a organization or MNC's [9].

\section{WHY INTERNATIONAL BUSINESS IS IMPORTANT:}

The importance of international business is to earning foreign exchange and export the good and services in all over the world and also developing better mutual understanding among the countries for ready to support each other and fulfil the need and improve the organisation's efficiency and get benefit from the government.

\section{CONCLUSION:}

In the future there is great scope in the international business because it gives you better strategic, technology, communication and foreign exchange markets. It also increases the globalization of the world economy it needs for the survival of business or a organization or MNC's [9]. The international business they required the trading and investing assets and liabilities to the risk profit to the business. The foreign exchange market is a global market that determine foreign exchange rate for all the currency and it include buying and selling and in the international business international business is the easier and important in the all over the country. International business has become a part entrepreneurship in the marketing and also achieving a goal, Job opportunities etc. And it helps you to reach more customer in the world and it also help you to gain profit in the business and it is the important to meet import and industrial needs

\section{REFERENCE:}

1. https://en.wikipedia.org/wiki/International_business - What is International Business

2. Ms. Ritu; Preeti Chawla. "Indian Environment for Entrepreneurship: A Study based on Literature Review". International Research Journal on Advanced Science Hub, 3, Special Issue ICIES-2021 4S, 2021, 18-21. doi: 10.47392/irjash.2021.104

3. https://courses.lumenlearning.com/wm-principlesofmanagement/chapter/responding-to-cultural-differences/Importance of Global business

4. https://courses.lumenlearning.com/suny-internationalbusiness/chapter/reading-what-is-international-business/-multinational companies

5. Vaishak Radhakrishnan. "E-Commerce industry and its effect on the world today". International Research Journal on Advanced Science Hub, 3, 2, 2021, 23-29. doi: 10.47392/irjash.2021.026

6. https://www.mywestford.com/blog/importance-of-technology-on-international-business/-use of technology in international business

7. Vikas R Gangadhar; Ajim Shaikh. "Cloud Technology and Return on Investment (ROI)". International Research Journal on Advanced Science Hub, 3, Special Issue ICEST 1S, 2021, 73-79. doi: 10.47392/irjash.2021.023

8. Sanjay Rai; Goyal S. B; Jugnesh Kumar. "Sentiment Analysis of Twitter Data". International Research Journal on Advanced Science Hub, 2, Special Issue ICSTM 12S, 2020, 56-61. doi: 10.47392/irjash.2020.261

9. $\quad$ Kavinya P; Nanthini K; Indumathi B. "Extracting top competitors from unorganized data-Review". International Research Journal on Advanced Science Hub, 1, 1, 2019, 10-16. doi: 10.47392/irjash.2019.02

10. https://www.americanexpress.com/en-us/business/trends-and-insights/articles/advantages-international-trade/- how to increase revenue in international business

11. https://circalingua.com/how-to-approach-international-clients/- technique Of reaching new customer

12. https://www.bauer.uh.edu/rsusmel/7386/ln1.pdf - Foreign Exchange Market

13. https://www.preservearticles.com/economics/what-are-the-important-functions-of-Function Of Foreign Exchange market

14. https://www.bondcapital.ca/learn/what-is-international-growth/- The International Growth in business 